Primljen / Received: 14.9.2011.

Ispravljen / Corrected: 3.9.2012.

Prihvaćen / Accepted: 30.9.2012.

Dostupno online / Available online: 15.10.2012.

\section{Model for selecting locations for construction of solar power plants}

Authors:

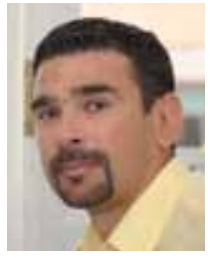

Asst. Prof. Ljudevit Krpan, PhD.

Primorje-Gorski kotar County

Dep. for regional development and Infr.

Ljudevit.Krpan@pgz.hr

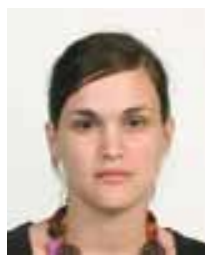

Višnja Šteko, landscape architect

OIKON Ltd.

Institute for Applied Ecology

vsteko@oikon.hr

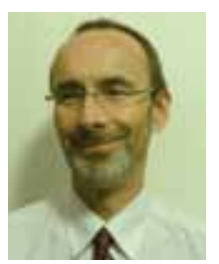

Željko Koren, MCE

OIKON Ltd.

Institute for Applied Ecology

zkoren@oikon.hr

\section{Ljudevit Krpan, Višnja Šteko, Željko Koren}

\section{Model for selecting locations for construction of solar power plants}

This paper provides an overview of location selection process for construction of solar power plants in the Primorje - Gorski kotar County. The proposed locations for solar power plants were based on the research results in the County's Physical Plan. This paper explains in detail the proposed model for selection of potential locations for solar power plants. The proposed model for selecting potential locations for solar power plants can be applied to any spatial unit, provided that it defines the necessary criteria by analysing different levels of detailed plans.

\section{Key words:}

Planning, multi-criteria analysis, solar power plants, physical planning documents

Sručni rad

Ljudevit Krpan, Višnja Šteko, Željko Koren

\section{Model odabira lokacija za gradnju sunčanih elektrana}

U radu se daje prikaz postupka odabira lokacija za smještaj sunčanih elektrana na području Primorsko-goranske županije primjenom metode dvojne analize. Temeljem rezultata istraživanja u Prostornom planu županije predložene su lokacije za smještaj sunčanih elektrana. Detaljno se analizira predloženi model odabira potencijalnih lokacija za sunčane elektrane. Navedeni model može se primijeniti na bilo koju prostornu cjelinu, uvažavajući potrebu da se kroz različite razine detaljnosti planova definiraju potrebni kriteriji.

Ključne riječi:

planiranje, višekriterijska analiza, sunčane elektrane, dokumenti prostornog uredenja

Fachbericht

Ljudevit Krpan, Višnja Šteko, Željko Koren

\section{Modell der Standortauswahl für den Bau von Solaranlagen}

In der Arbeit ist eine Darstellung des Verfahrens zur Standortauswahl für Solaranlagen auf dem Gebiet der Gespanschaft Primorje - Gorski kotar unter Anwendung der Methode der Zweitanalyse gegeben. Auf Grund der Forschungsresultate wurden in dem Raumplan der Gespanschaft Standorte für die Solaranlagen vorgeschlagen. Das vorgeschlagene Modell der Auswahl potentieller Standorte für Solaranlagen wird detailliert analysiert. Das angeführte Modell kann auf alle beliebigen Gebietseinheiten angewandt werden, dabei den Bedarf in Erwägung ziehend, dass auf verschiedenen Plandetailebenen die notwendigen Kriterien definiert werden.

Schlüsselwörter:

Planung, Multi Criteria Analysis, Solaranlage, Raumordnungsdokumente 


\section{Introduction}

In 2011, the Primorje - Gorski kotar County (PGKC) initiated activities aimed at preparation of the new county-level Comprehensive Development Plan. One of the reasons for preparation of this plan was the need to give an additional impulse to the use of renewable sources of energy (RSE) by providing appropriate physical planning preconditions for this activity. The current Comprehensive Development Plan of the Primorje - Gorski kotar County (PPPGŽ) enables local communities to recognize and define, in the scope of their own planning documents, the exact locations for this activity, and conditions for proper positioning of RSE facilities within their territory (Official Gazette of the PGKC, issues 14/00, $12 / 05,50 / 06,08 / 09,03 / 11$, Article 97). The primary wish of the PGKC is to promote and encourage the use of RSE, and hence also of the solar energy, at the level of individual users (households, hotels, etc.), and to stimulate development of solar and wind plants as separate facilities that need to be positioned outside of inhabited areas. The study of possible use of space for construction of solar plants in the territory of the PGKC was prepared in order to gather appropriate expert information and to determine solar plant locations to be included in development planning documents.

The paper also offers a detailed analysis of the GIS (Geographic Information System) model that has been used for selection of potential solar plant locations within the territory of the Primorje-Gorski kotar County. The results of this study will be used to determine locations in the PPPGŽ as well as relevant positioning requirements. This will enable procurement of location permits based on PPPGŽ, which will facilitate and encourage investments in this field. The objective of this paper is to confirm applicability of this approach and methods used for determining priorities in the realization of solar power plants. The above location selection model can be used for any segment of space, provided that appropriate criteria are defined for various plan detail levels.

\section{Multicriteria analysis}

Making decision about the most favourable solution at the infrastructure system planning stage is highly complex because of numerous objectives that have to be met in the process. The level of realization of such objectives is evaluated using a number of criteria and measures and, at that, various limitations have to be taken into account. The multicriteria analysis can be defined as a support model to the decision making process that is composed of a set of solutions (alternatives to be ranked or sorted by the decision maker), set of criteria (quantitative and qualitative, based on a number of indicators), and set of values (ratings) of each alternative according to each criterion, all based on cooperation between various experts and local community representatives [1].
Space planning documents are the basis for space development considerations. These documents are prepared by the state, and by regional and local government units, and are then adopted by public representative bodies (Parliament of the Republic of Croatia, county assemblies or municipal/ district councils), depending on the level of a particular space planning document. That is why the most favourable space planning alternative/solution is not made by experts only, but rather the decisive role is very often played by politicians (who lack specialized technical knowledge). This is precisely why the multicriteria analysis is considered to be a highly objective tool for the presentation and selection of the most favourable or compromise solutions [2].

When considering methodology of multicriteria analysis, it should be noted that its use in space planning implies a systemic analysis of the problem. Planned locations of infrastructural facilities may be considered acceptable only if the solution offered simultaneously meets environmental protection and economic criteria. In many instances, these two groups of criteria are not mutually compatible. That is why changes to alternative solutions are proposed until best mutually acceptable conditions are found.

Considering the complexity of the issue, the selection/ rating of potential infrastructure project locations is usually conducted in two steps: selection of possible locations through elimination of inadequate zones, and then comparative evaluation of the remaining locations/sites.

At that, elimination criteria define values, or a range of values, according to which a location is not favourable. This deficiency of the location can not be compensated by greater quality of this location according to other criteria. In other words, if a location does not meet required conditions according to the criterion selected, then it is unacceptable regardless of other criteria. The main objective of the selection and use of elimination criteria is to eliminate the greatest possible part of the area under study, so as to simplify the procedure of finding and evaluating other potential locations.

Comparison criteria are rules for the evaluation of potential locations. Once the elimination criteria have been applied, criteria for comparison of remaining locations are determined. When determining comparison criteria, attempts are made to make them independent from each other, and to take into account all differences (technical-technological, environmental, safety and economic) between locations included in the evaluation. It should be noted that the selection of criteria is dependent on the relevance of criteria for the selection process. If there is no difference between the locations according to a given criterion, then this criterion can simply be omitted. Similarly, inapplicable criteria can also be omitted [2].

In order to ensure high quality of the planning process, it is also indispensable to know well and to analyze condition of the space under study. The GIS technology is an excellent substitution for the personal visit to and inspection of the 
location. The GIS enables inspection of the entire area all at once, which greatly facilitates analysis of the total area with all of its particularities, while also ensuring an equal and equitable treatment of the space under study. The GIS is used not only as a source of up-to-date and good-quality statistical data, but also as a programming tool in the decision-making process.

During analysis of optimum solar plant positioning locations, the GIS database and GIS tools can assume three separate roles. The first of these roles is related to the determination of highly valuable land units, in the segment of environmental evaluation of individual solutions, during implementation of the multicriteria decision-making process. The second equally significant GIS role is assumed during treatment of available statistical data for definition of individual space zones, depending on spatial distribution of various facilities (housing, industry, recreation, tourism, etc.), i.e. the data on the total planned economic, demographic, and socioeconomic movements within a zone. The third role is related to the procedure for preparing a technical space planning report, as a basis for optimum positioning of individual infrastructural facilities, taking into account available environmental protection elements, and the data gathered during geological, hydrological and other studies [2].

\section{General information on solar power plants}

Direct use of solar power for various applications (generation of thermal energy, electric energy, etc.) is more acceptable for our environment when compared to the use of fossil fuels. However, possible negative influences include impact on some types of flora and fauna, and/or impact on natural habitats, and possible detrimental effects on natural landscape.

Three main principles may be differentiated with regard to solar energy use: thermal energy, concentrated energy, and photovoltaic energy. The sun-generated thermal energy is the technology of converting solar radiation energy into thermal power. The concentrated solar power (CSP) is the technology in which the sun radiation is concentrated at solar thermal plants by means of high temperature collectors using lenses and/or mirrors. This generates high temperatures and heats liquids or gases which set in motion, by evaporation or expansion, thermal plants (steam turbines) or generators that convert this thermal energy into electricity. Solar thermal plants are most often equipped with heat tanks which enable production of electricity even during cloudy weather and at night-time. The solar photovoltaic energy is the technology in which the sun power is directly converted into useful forms of energy by absorbing solar photons (light particles acting as separate energy units), and/or by converting a part of the Sun's energy into electric energy (photovoltaic cells), or by storing a part of the energy into a chemical reaction (e.g., conversion of water into hydrogen and oxygen). Photovoltaic power stations are photovoltaic systems that are directly connected to the public power-supply grid. According to their nominal capacity, these systems are classified as follows: $0.5 \mathrm{MW}$ to $10 \mathrm{MW}$, from 10 $\mathrm{MW}$ to $30 \mathrm{MW}$, and from $30 \mathrm{MW}$ onward. It should be noted that in case of the CSP technology the impact on environment is greater when compared to photovoltaic systems. Thus, the CSP technology may bring about reduced visual quality of space due to construction of towers (which range from 50 to more than $100 \mathrm{~m}$ in height), or may harm water resources due to use of thermal oil or dissolved salt. That is why this technology should not be used in karst areas and in areas with low rainfall and limited availability of water resources.

\section{Methodology for selecting solar plant locations in PGK County}

According to its geographic features, the PGK County may be described as highly varied and diverse. Thus, the county is formed of three micro-regions defined according to their distinct physical properties and level of development: Gorski kotar, littoral area, and Kvarner islands. It is evident that one of the main criteria for development of solar power plants is the intensity of solar radiation (solar potential) and that, from this point of view, it would be preferable to choose among island-based locations. This does not mean that the Gorski kotar area is generally inadequate for construction of solar plants. In fact, it is adequate but the investment return time would be somewhat longer. On the other hand, some island locations may prove fully inadequate due to steepness of terrain.

Before actual evaluation of suitability of locations for solar plant positioning, it was necessary to determine the types of facilities that would be appropriate for positioning in the PGK County, as well as their volume or size. It was concluded that the technology involving photovoltaic cells is more suited for the County when compared to the concentrated solar power technology.

This activity was followed by defining space requirements and solar plant accommodation possibilities. It was established that about 5 hectares of space would be needed for installation of a $1 \mathrm{MW}$ photovoltaic system, with continuous linear dependence between the power and space. It was also established that, due to natural relief constraints, it would not be appropriate to build solar plants of more than $10 \mathrm{MW}$ in the territory of the PGK County.

Then the dual space analysis method (involving development potential analysis, and the analysis of fulfilment of protection objectives) was adopted for the selection of potential solar plant locations. This method is based on systemic approach to the resolution of environmental protection problems in space planning activities. Separate modelling of attractiveness and vulnerability of space is based on opposite value systems and on the corresponding rating criteria. When defining attractiveness of space, only the development aspect (economic benefit or interest) is taken into account. On the 
other hand, when vulnerability is defined, the criterion used in evaluation is public interest to ensure proper environmental protection. It is precisely this dual approach to space quality simulation that enables planners to properly analyse value systems in space.

Space evaluation based on convenience model is a procedure conducted in two steps, i.e. through attractiveness model and vulnerability model. Favourable, value-sensitive locations are obtained through synthesis of the attractiveness and vulnerability models, and then the locations with the highest convenience ratings are selected, taking into account the size of the area needed for realization of the planned activity. The use of the convenience model enables utilization of an unlimited number of georeferenced space data that are clearly and transparently systematized and evaluated during the procedure itself, depending on the value model used (development or protection). The space information dataset was prepared using the ArcView 3 and ArcGis 9 program packages, while the modelling itself was conducted using the computer software ProVal. The size of a homogeneous space unit (pixel) was defined as $100 \times 100$ $\mathrm{m}$ for the evaluation of space through attractiveness and vulnerability models, as the county development plan is normally made on the scale of $1 / 100,000$. During definition of criteria, the analysis of the objective was not included in the methodology.

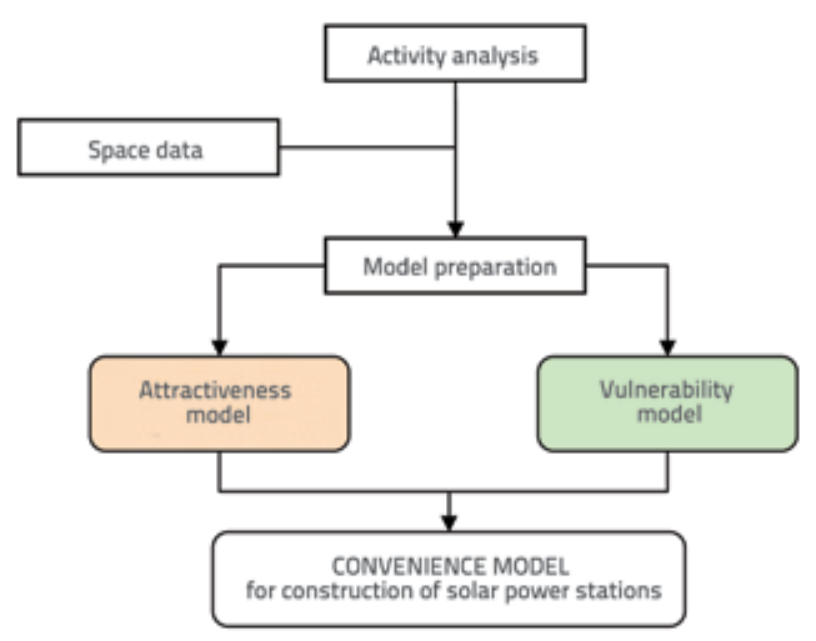

Figure 1. Flow diagram for convenience mode [3]

The procedure for estimating suitability of an area for construction of a solar power station is composed of the following steps:

1. Analysis of activity (orientation of occurrences, their scope and possible environmental impacts).

2. Preparation of a database containing space data presented in form of thematic maps.
3. Preparation of attractiveness model (using elimination and comparison criteria).

4. Preparation of vulnerability model.

5. Preparation of convenience model (by combining attractiveness and vulnerability maps), Figure 1.

6. Definition of a narrow and broad selection of locations.

7. Inspection of the location and field data gathering.

8. Evaluation and rating of results.

\subsection{Use of space attractiveness model for solar power station positioning}

Spatial properties favourable for solar plant positioning are defined in the attractiveness model, which includes development criteria. Attractiveness matrices are prepared based on the spatial attractiveness data and solar plant positioning criteria. These matrices are used to allocate an appropriate weighting to each criterion. The areas with best ratings are considered to be the most attractive ones. The attractiveness model is used to analyse physical space using the elimination and comparison criteria.

In the first phase of selection, elimination criteria are used to evaluate the entire space, and then those areas that are totally inappropriate for solar plant construction are rejected. Such areas are natural relief forms which, due to unfavourable inclination (mountain ridges and hilltops), considerable shading, or restricted space (canyons), can not be considered appropriate for construction of solar power stations. This group also includes special purpose spaces for which a special regimen of use and protection is specified. Such spaces are for instance protected coastal areas, and national borders with surrounding space of no less than $1 \mathrm{~km}$, which are discarded due to possible crossborder influences. Nature localities protected by law (national parks, nature parks, forest parks, special nature reserves, strict nature reserves, and significant landscapes) and cultural heritage sites specified by law (archaeological zones and/or monuments, ethno-zones and/or monuments, urban communities, rural communities, memorial zones, historic buildings), are also discarded as highly valuable natural and cultural zones that are therefore not appropriate/attractive for construction of power plants. Areas unattractive for this usage are also areas in which protected sources of drinking water are located. Such areas are the first protection zones (IA and IB) in which all activities, other than those related to the use, cleaning, and transport of water toward the water supply system, are banned. Equally discarded are all built-up areas, infrastructure zones (power and transport infrastructure), and areas under the sea/water. This is followed by space evaluation using value matrices. The attractiveness criteria selected are evaluated in space by means of matrices (attractiveness sub-models). Then all matrices are combined into a single final attractiveness model, Figure 2. To place emphasis on different significance of 


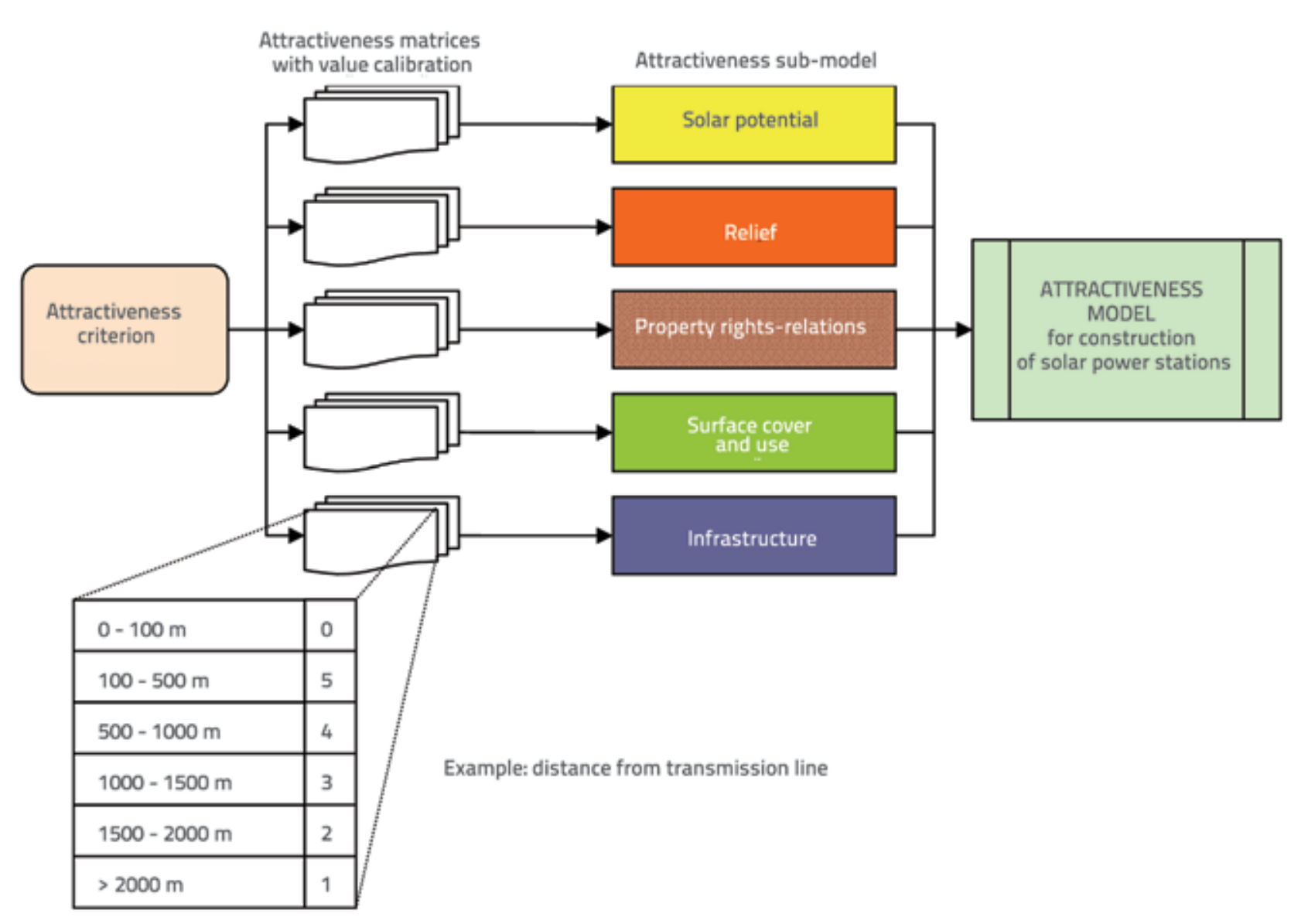

Figure 2. Preparation of attractiveness matrix and merging sub-models into the attractiveness model [3]

individual parameters, a weighting factor is attributed to each matrix. All values are multiplied with the weighting factor values in order to determine (increase or reduce) their rating in the subsequent association procedure. Weighting factors are expressed as decimal percentages (i.e. numbers between 0 and 1). The final result of association in the attractiveness model is the value map with localities rated on the scale from 0 to 5 according to their attractiveness. At that, the areas that have obtained high ratings are in fact areas with greater attractiveness for solar plant positioning.

After application of elimination criteria in the territory of PGK County, the map of eliminated areas was drawn. It was established that these eliminated areas occupy as many as $60.84 \%$ of the total area under study. Out of the total area, $4.24 \%$ is considered as the most attractive (rating: 5), $9.05 \%$ is considered as highly attractive (rating: 4), $19.33 \%$ as attractive (rating: 3), and $6.54 \%$ as hardly attractive for construction of solar plants (rating: 2). At that, the greatest number of the most attractive areas are located on the island of Cres, and then on the islands of Krk, Rab and Lošinj. Some of the most attractive areas, and more of the highly attractive ones, are located in the littoral, while they are quite rare in Gorski kotar.

\subsection{Use of space vulnerability model for solar power station positioning}

When vulnerability of an area is modelled, the model in fact simulates the way in which the planned activity might affect the area under study. This modelling enables estimation of acceptability or unacceptability of the activity based on the following logical assumption: in areas where the level of quality is higher, the level of acceptability of the planned activity is lower. This model measures all qualities of the environment that could be put in jeopardy because of construction of solar power stations. The evaluation is based on three aspects of protection which safeguard:

- natural environment (vulnerability of natural qualities, including land flora and fauna),

- human environment (vulnerability of cultural and visual qualities), and

- resources (vulnerability of physical space regarded as a resource for forestry, agriculture, and water industry).

In the first step, the vulnerability model defines possible sources of negative influence of an activity (division of an activity into working phases and determination of the way 


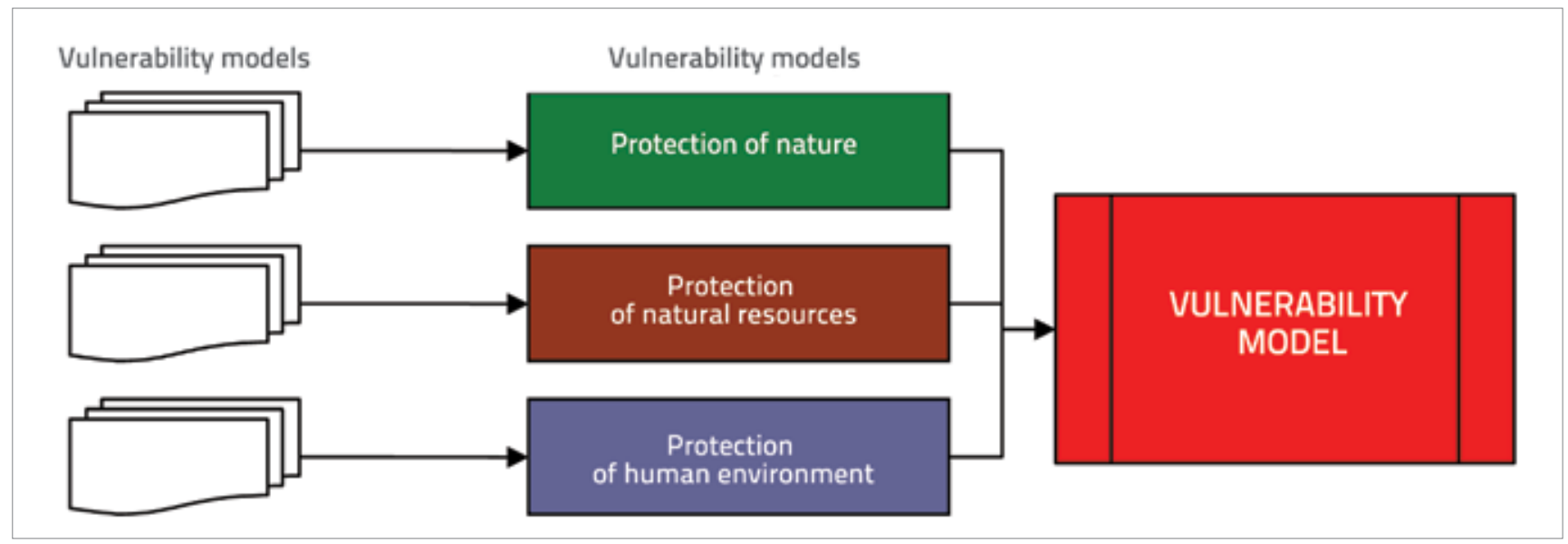

Figure 3. Merging vulnerability submodels and models into an overall vulnerability model

in which the environment is physically affected by each of these phase), Figure 3. This is followed by establishment of interaction matrices (registration of environmental changes and attribution of significance to such changes). The significance of influence of individual elements of the planned activity on the quality of environment is estimated in the interaction matrix. Then the scoping method is used to rank the influences, i.e. to separate those components of the environment that would be mostly affected by the planned activity. To take into account the complexity of the area under study, and to facilitate implementation and understanding of results, the vulnerability is presented through several vulnerability models (vulnerability of natural qualities, vulnerability of terrestrial flora and fauna, vulnerability of space as a resource for forestry, vulnerability of space as a resource for agriculture, vulnerability of space as a resource for water economy, vulnerability of cultural qualities, and vulnerability of visual qualities of space. Models are selected based on recognized impacts the activity has on environment, significance of planned space, and taking into account the available information. The way matrices are fused into vulnerability submodels, and the way the latter are fused into the final vulnerability model, is defined by the type of data used, and by submodel logic. The final result of this fusing into the vulnerability model is the value map in which vulnerability of individual areas is rated from 0 to 5 . At that, the areas that have obtained high ratings are in fact areas with greater vulnerability with regard to solar plant positioning. As vulnerability criteria were very stringent (only the highest value was registered), a relatively large number of vulnerable areas was obtained for the PGK County. Out of the total area under study, $48.89 \%$ of areas were rated as the most vulnerable ones (rating:5), $36.67 \%$ were rated as highly vulnerable (rating: 4), $13.55 \%$ as vulnerable (rating: 3 ), and only $0.58 \%$ were rated as low vulnerability areas (rating: 2 ). It was established that the greatest number of the most vulnerable areas are situated in the littoral zone, while the remaining most vulnerable zones are uniformly distributed across other parts of the County. The number of the most vulnerable zones is somewhat lower on the island of Cres.

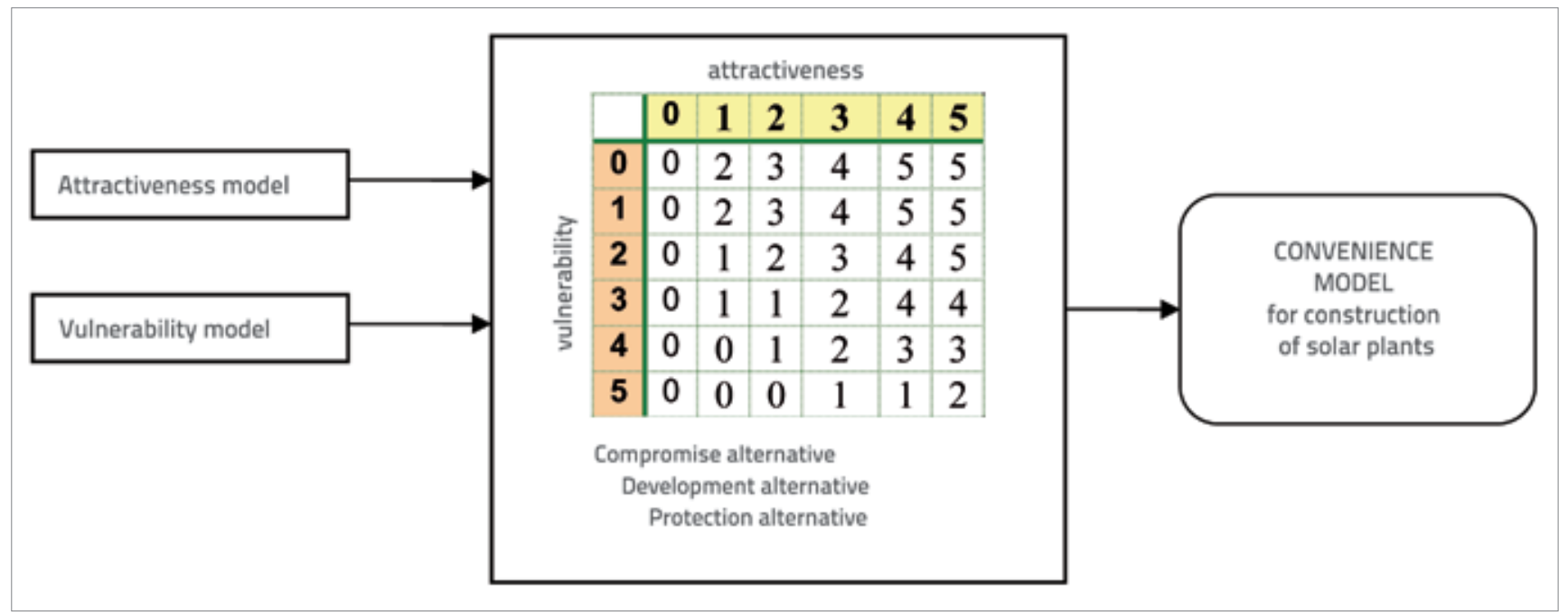

Figure 4. Merging the vulnerability and attractiveness model into the final convenience model for solar plant positioning [3] 


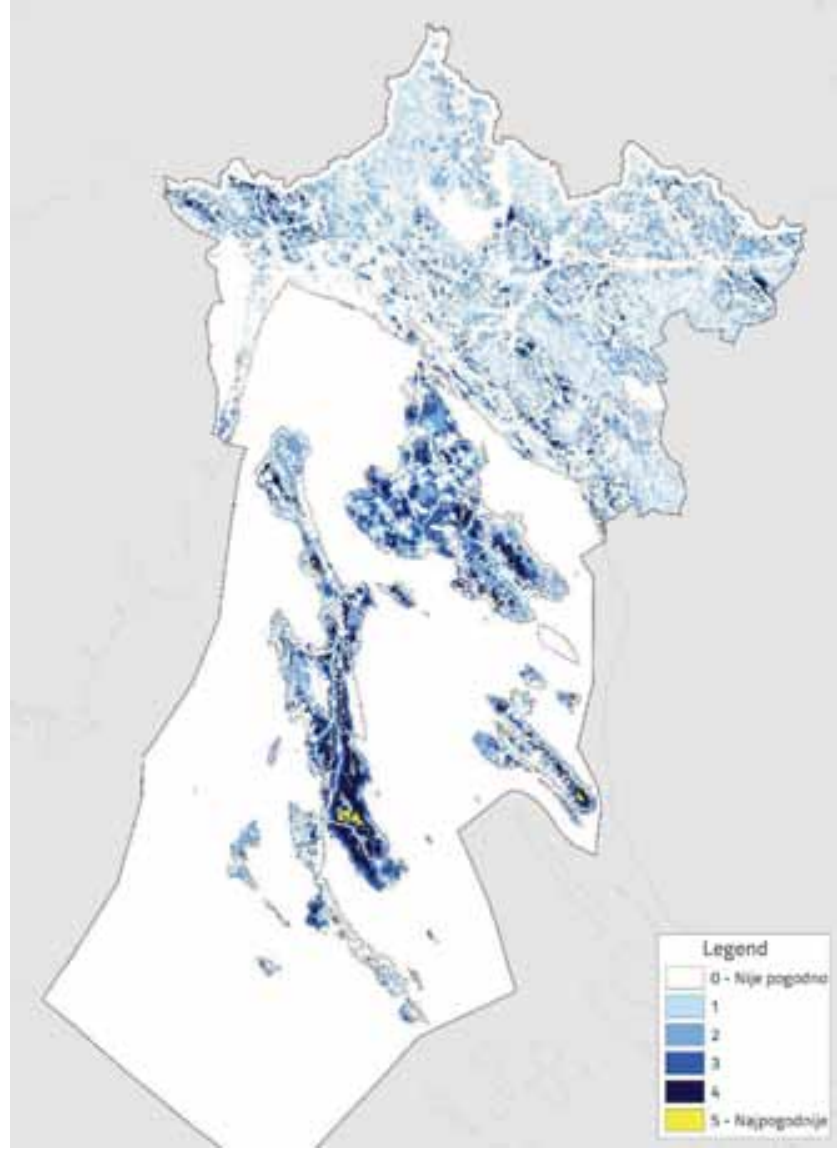

Figure 5. Convenience map showing convenient solar plant locations (compromise alternative)

\subsection{Use of space convenience model for solar power station positioning}

In the context of positioning a certain activity in a given area, the convenience can be described as the possibility of space to accept development of this activity (and of everything the implementation of this activity implies). The convenience model is obtained by merging the final attractiveness and vulnerability model for a certain activity, via the value matrix. The distribution and area of the convenient space are directly influenced by the strictness of criteria that are used to allocate convenience ratings within the matrix. Thus, several sub-alternatives should be created in order to select an appropriate model based on results obtained. When the two-dimensional interaction matrix is used, the values of attractiveness and vulnerability models "overlap" according to the following logic: the higher the attractiveness rating and the lower the vulnerability rating, the higher the convenience rating, Figure 4.

Potential solar plant positioning locations are obtained through implementation of the convenience model (protection alternative, development alternative, and compromise alternative). At that, in the combined matrix, greater weight

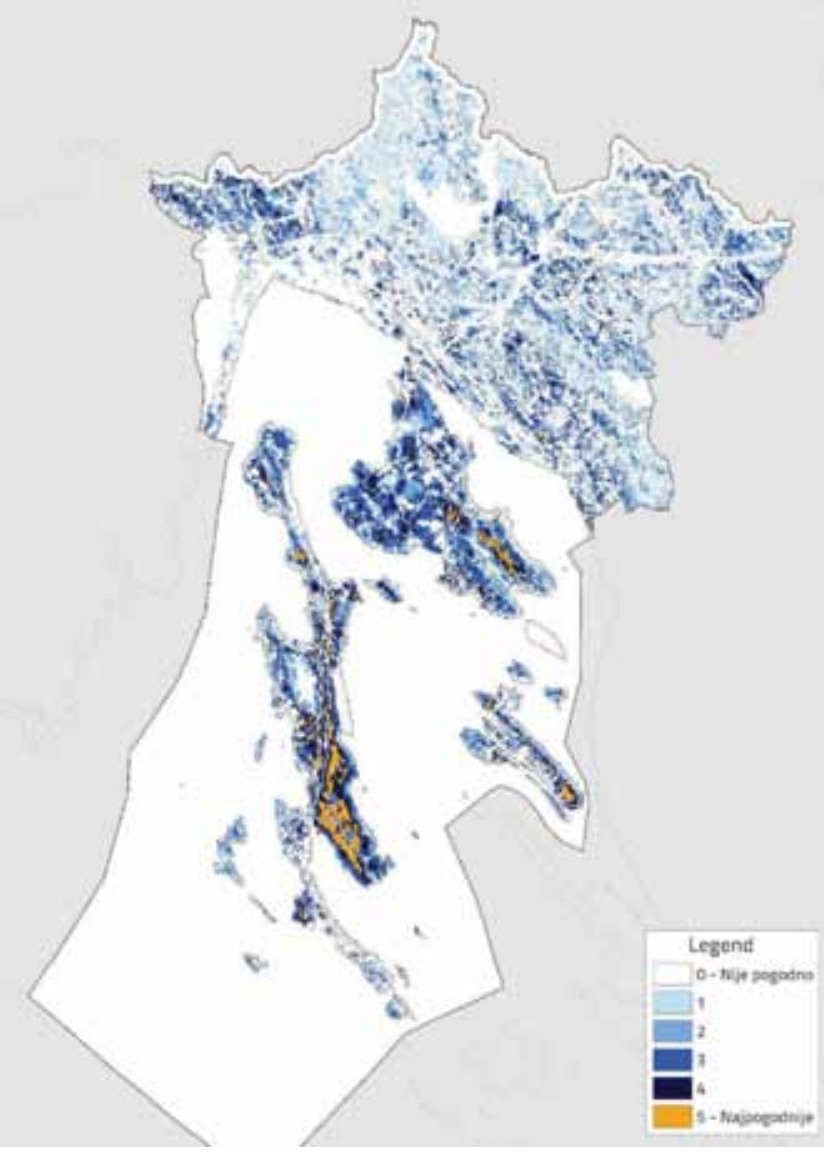

Figure 6. Convenience map showing convenient solar plant locations (development alternative)

is allocated to attractiveness in the development alternative, while greater weight is given to vulnerability in the protection alternative.

In case of PGK County, the highest convenience rating for the compromise alternative was obtained for $0.13 \%$ of the total area under study, while in case of development alternative the highest convenience rating was obtained for $1.45 \%$ of the total area considered. This means that in compromise alternative 477 ha ( 1 pixel $=1$ ha) of space is suitable for solar plant positioning, while in case of development alternative this space rises to 5,308 ha. It can be seen from the convenience map - compromise alternative (Figure 5) that the greatest number of the most convenient areas are situated on the island of Cres, while the islands of Krk and Rab each have one such area. In case of development alternative, the number of the most convenient areas is much greater, Figure 6. Most of these areas are also located on the island of Cres, but some are also situated on the islands of Krk, Rab and Lošinj, near Vinodol valley, and to the north of the town of Rijeka, towards the border with Slovenia.

The total convenience rating and individual ratings can be interpreted as an aggregate rating of project development risk when compared to other locations: the higher the rating of a 
location is, the lower overall project risks can be assumed. It can be concluded based on multicriteria analysis results that it would be appropriate to consider the possibility of planning and building solar plants starting with the ones with higher ratings and continuing with the ones with lower ratings. In the end, the quality of the final result will always correspond to the quality of input assumptions, which is especially true for assumptions about solar potential and possibility of connection to the public power grid. A more detailed insight into risk relationships can be obtained by additional analyses of the shortlisted locations. This would include a more detailed definition of the space distribution of sun potential in order to estimate usability of power, a more detailed analysis of the possibility and way of ensuring connection to the power grid, a detailed estimate of the influence of geomorphology on technical implementation, a detailed analysis of expected impacts on nature and environment, etc. All these activities could be regarded as possible further steps in the development and use of methodology for the selection and rating of future solar plant locations.

\section{Conclusion}

The method with dual analysis of space, based on systemic approach to the resolution of environmental protection problems in space planning, was applied for selection of solar plant locations within the PGK County. The convenience model was obtained by merging the attractiveness model and vulnerability model, via the value matrix. A number of potential locations that are proposed for inclusion in the Comprehensive Development Plan of the PGK County were selected by using the multicriteria analysis (convenience model). The shortlist of potential locations (15 locations), obtained according to the compromise alternative, was analysed by data checking via matrices, which were used to evaluate and then to rate individual locations.

A separate modelling of attractiveness and vulnerability of space was based on opposite value systems and on the corresponding evaluation criteria. In case of attractiveness of space, only the development aspect - economic benefit or interest - was taken into account, while in case of vulnerability the criterion used in evaluation was public interest to ensure proper environmental protection. The types of facilities that would be appropriate for positioning in the PGK County, as well as their volume or size, were determined before actual evaluation of suitability of locations for solar plant positioning. A significant step forward in the development of strategic space planning documents, county-level comprehensive plans in particular, has been made through implementation of this study. It was established that the proposed solar plant locations constitute only a basis that can further be expanded through lower-rank plans, and so the real value of the study lies in clearly defined solar plant positioning criteria. The results of this study confirm, both scientifically and methodologically, that systemic planning is highly sensible and justified, and that good quality supporting documents must be prepared as a technical basis for preparation of strategic space planning documents.

\section{REFERENCES}

[1] Kareluša, B., Ožanić, N.: Određivanje prioriteta u realizaciji vodnogospodarskih planova, Gradevinar 63, (2011.), str. 151-161

[2] Krpan, Lj.: Integralni prostorno-prometni model urbanističkog planiranja, doktorska disertacija, Pomorski fakultet u Rijeci, Rijeka, 2010. (neobjavljen)
[3] Šteko, V. (voditeljica studije): Studija mogućnosti korištenja prostora za gradnju sunčanih elektrana na području PGŽ, OIKON d.o.o. Institut za primijenjenu ekologiju, Zagreb, 2010.

[4] Antonić, O., Križan, J., Milostić, M., Bukovec, D.: Stručne podloge, kriteriji i metodologija za izbor lokacija za izgradnju solarnih elektrana u Republici Hrvatskoj, OIKON d.o.o. Institut za primijenjenu ekologiju, Zagreb, 2009. 